\title{
Handbook of Florida Water Regulation: Environmentally Safe Practices ${ }^{1}$
}

Michael T. Olexa, Luke D'Isernia, Laura Minton, Dulcy Miller, and Sarah Corbett ${ }^{2}$

\section{Preface}

This handbook is designed to provide an accurate, current, and authoritative summary of the principle Federal and Florida laws that directly or indirectly relate to agriculture. This handbook should provide a basic overview of the many rights and responsibilities that farmers and farmland owners have under both Federal and Florida laws as well as the appropriate contact information to obtain more detailed information. However, the reader should be aware that because the laws, administrative rulings, and court decisions on which this handbook is based are subject to constant revision, portions of this publication could become outdated at anytime. Several details of cited laws are also left out due to space limitations.

This handbook is distributed with the understanding that the authors are not engaged in rendering legal or other professional advice, and the information contained herein should not be regarded as a substitute for professional advice. This handbook is not all inclusive in providing information to achieve compliance with the Federal and Florida laws and regulations governing water protection. For these reasons, the use of these materials by any person constitutes an agreement to hold harmless the authors, the Florida Cooperative Extension Service, the Institute of Food and Agricultural Sciences, and the University of Florida for any liability claims, damages, or expenses that may be incurred by any person as a result of reference to or reliance on the information contained in this handbook.

\section{What Are the Soil and Water Conservation Districts?}

Florida currently has 62 Soil and Water Conservation Districts (SWCD), which are self-governed by a board composed of five locally elected supervisors. Candidates are elected in a general election to a four-year term. Vacancies are filled by appointment by the remaining supervisors until the next regular election. Under the authority of the Soil Conservation Act, the SWCDs identify areas within each district that require further conservation

1. This is EDIS document FE600, a publication of the Food and Resource Economics Department, Florida Cooperative Extension Service, Institute of Food and Agricultural Sciences, University of Florida, Gainesville, FL. Published December 2005. Please visit the EDIS website at http://edis.ifas.ufl.edu.

2. Michael T. Olexa, Professor, Food and Resource Economics Department, Florida Cooperative Extension Service, Institute of Food and Agricultural Sciences, University of Florida, Gainesville, FL; Director, Agricultural Law Center, University of Florida, Gainesville, FL; and Chair, Agricultural Law Committee of The Florida Bar. Luke D'Isernia, former student (graduated cum laude in 2005), Levin College of Law, University of Florida, Gainesville, FL. Laura Minton, Attorney, Dean, Mead, Egerton, Bloodworth, Capouano, and Bozarth, Orlando, FL. Dulcy Miller, attorney, Foley and Lardner, LLP, Orlando, FL. Sarah Corbett, Attorney, Florida Second District Court of Appeal, Lakeland, FL.

The Institute of Food and Agricultural Sciences (IFAS) is an Equal Opportunity Institution authorized to provide research, educational information and other services only to individuals and institutions that function with non-discrimination with respect to race, creed, color, religion, age, disability, sex, sexual orientation, marital status, national origin, political opinions or affiliations. U.S. Department of Agriculture, Cooperative Extension Service, University of Florida, IFAS, Florida A. \& M. University Cooperative Extension Program, and Boards of County Commissioners Cooperating. Larry Arrington, Dean 
measures. SWCDs are advisory in nature and do not enforce regulations.

The SWCDs may conduct research, construct works for soil and water conservation, and develop comprehensive plans for soil erosion control and flood prevention. In addition, the SWCDs may adopt land-use regulations that may require certain agricultural practices such as contour cultivation, strip cropping, and the planting of erosion-preventative vegetation. However, the SWCDs do not have the power to enforce these regulations.

The Natural Resources Conservation Service (NRCS), a branch of the USDA, works with the SWCD boards to offer farmers assistance through such programs as the Conservation Technical Assistance Program in conserving and maintaining their soil, water, and other natural resources against such damage as topsoil and water erosion of their fields. It also helps farmers limit water contamination and water misuse on their farms. All NRCS measures are voluntary and are often referred to as Best Management Practices.

\section{What Are Best Management Practices?}

Farmers interested in limiting their exposure to unwanted penalties and liabilities should utilize Best Management Practices (BMP). BMPs are management and cultural practices that allow the farmer to get the most beneficial use out of the land while preserving the purity of water bodies. These practices are defined by research and field testing to be the most effective and practicable methods. The primary sources of water contamination are suspended solids, nutrients, animal wastes, and pesticides. When these substances are present in excess, algae blooms, fish kills, sedimentation, health hazards, aesthetic changes, and modifications of plant and animal species diversity may result.

As mentioned previously, the OAWP, under DACS, is actively involved in the development of BMPs, addressing both water quality and water conservation on a site specific, regional, and watershed basis.
Both the NRCS and DACS limit these problems by involving farmers in a variety of conservation practices (BMP). The practices vary given the agricultural system in use, the land involved, the waters being affected, and the potential pollutants. The NRCS and DACS will identify the problem, design an appropriate BMP, oversee the implementation of the BMP, and monitor the effectiveness of the BMP; however, the NRCS will not pay for the BMP.

An example of a BMP is a natural or constructed waterway maintained with stream bank vegetative cover in order to prevent soil erosion and to filter nutrients. Because BMPs change as often as technology changes, be sure to keep abreast of the most current available BMPs. Specific inquiries should be directed to your local Cooperative Extension Service, Soil and Water Conservation District, and the OAWP.

\section{Acknowledgments}

The authors are indebted to the personnel of both state and federal agencies who provided their time and advice in the preparation of this handbook. The authors are especially indebted to Richard Budell of the Office of Agricultural Water Policy of the Florida Department of Agriculture and Consumer Services for providing funds for the development of this publication. 